\title{
Use of a vacuum sponge to expedite healing of a large peripancreatic collection
}

Infected pancreatic necrosis carries a poor prognosis, with high rates of morbidity and mortality [1]. Open surgical necrosectomy is associated with higher rates of major complications and death compared with minimally invasive approaches [2] such as transgastric endoscopic necrosectomy. When a transgastric approach does not provide complete access or drainage, the percutaneous endoscopic route offers an additional modality for larger collections [3]; however, treatment duration may be prolonged given the extent of necrosis, with patients requiring multiple imaging and necrosectomy sessions.

A 56-year-old woman presented with fever and epigastric pain 2 months after an episode of severe necrotizing pancreatitis. Repeat abdominal computed tomography revealed a $22-\mathrm{cm}$ infected walledoff pancreatic necrotic collection containing gas and fluid and tracking into the left paracolic gutter. Broad-spectrum antibiotics were started and a percutaneous catheter was placed by interventional radiology to provide subsequent access for percutaneous endoscopic necrosectomy. An endoscopic ultrasound- guided cyst-gastrostomy with a 15-mm lumen-apposing metal stent (LAMS) was successfully performed ( $\vee$ Video 1 ). The percutaneous drain was exchanged for a fully covered esophageal metal stent of sufficient length to extend from the skin to the cavity. The patient underwent simultaneous transgastric and percutaneous necrosectomies, eventually allowing for both endoscopes to meet within the necrotic cavity. To expedite healing, a vacuum sponge mounted on a flexible plastic tube was placed deep within the collection cavity from the percutaneous access point and was connected to suction to accelerate drainage and promote formation of healthy granulation tissue. Two plastic stents were also placed across the LAMS cyst-gastrostomy. Serial endoscopic necrosectomies were repeated in the same manner over a 3-week period. The patient's symptoms resolved after completion of the necrosectomies and repeat imaging revealed resolution of necrosis.

A complex infected peripancreatic collection in the setting of necrotizing pancreatitis can be successfully managed by a combination of transgastric and trans-

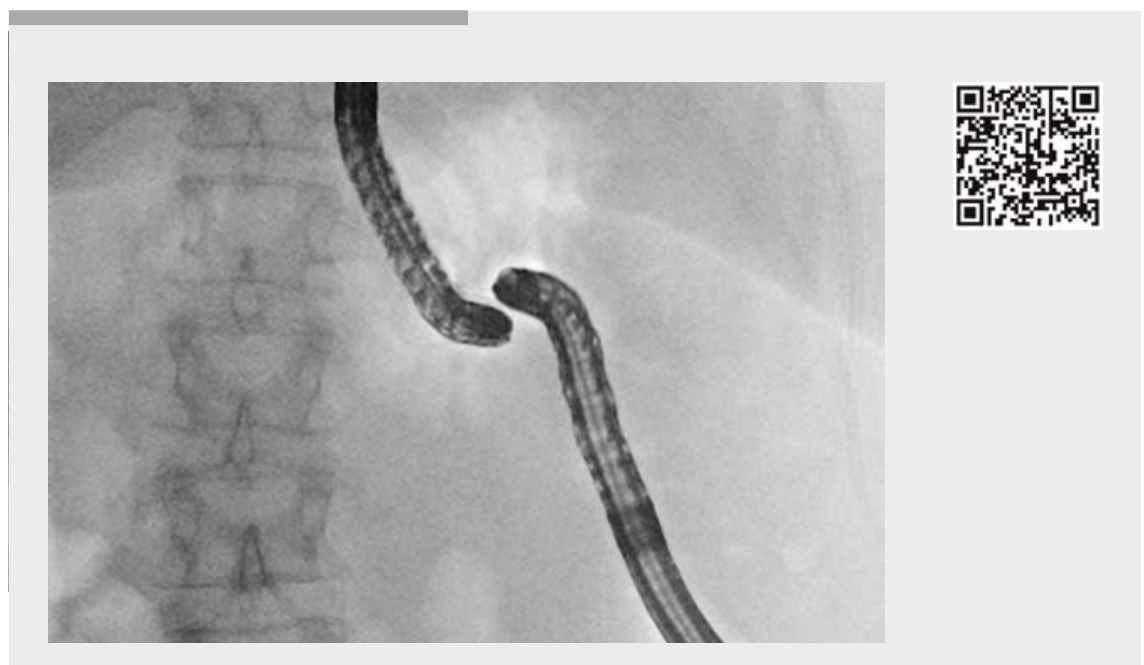

Video 1 Use of a vacuum sponge to expedite healing of a large peripancreatic collection.

cutaneous endoscopic necrosectomy, thereby avoiding surgery [3]. Use of endoscopic vacuum-assisted drainage can serve as an adjunct to facilitate and expedite healing by reducing the number of endoscopic sessions [4].

Endoscopy_UCTN_Code_TTT_1AR_2AI

Competing interests

Drs. Carr-Locke and Sharaiha are consultants for Boston Scientific, Olympus, and Medtronic.

The authors

Kaveh Hajifathalian' ${ }^{1}$, Zaid H. Tafesh' ${ }^{1}$, Qais Dawod $^{1}$, Monica Saumoy ${ }^{2}$, Tibor Krisko ${ }^{1}$, David Carr-Locke' ${ }^{1}$, Reem Z. Sharaiha ${ }^{1}$

1 Division of Gastroenterology and Hepatology, New York Presbyterian Hospital/ Weill Cornell Medicine, New York, New York, United States

2 Department of Medicine, Perelman School of Medicine, University of Pennsylvania, Philadelphia, Pennsylvania, United States

Corresponding author

Reem Z. Sharaiha, MD

Division of Gastroenterology and Hepatology, New York Presbyterian Hospital/ Weill Cornell Medicine, 1305 York Avenue, 4th floor, New York, NY 10021, United States Fax: +1-646-9620110

rsharaiha@gmail.com 


\section{References}

[1] Whitcomb DC. Clinical practice. Acute pancreatitis. N Engl J Med 2006; 354: 2142 2150

[2] van Santvoort HC, Besselink MG, Bakker OJ et al. A step-up approach or open necrosectomy for necrotizing pancreatitis. N Engl J Med 2010; 362: 1491 - 1502

[3] Dhingra R, Srivastava S, Behra S et al. Single or multiport percutaneous endoscopic necrosectomy performed with the patient under conscious sedation is a safe and effective treatment for infected pancreatic necrosis (with video). Gastrointest Endosc 2015; 81: 351-359
[4] Wedemeyer J, Kubicka S, Lankisch TO et al. Transgastrically placed endoscopic vacuumassisted closure system as an addition to transgastric necrosectomy in necrotizing pancreatitis (with video). Gastrointest Endosc 2012; 76: 1238 -1241

\section{Bibliography}

DOI https://doi.org/10.1055/a-0885-9416

Published online: 30.7.2019

Endoscopy 2020; 52: E1-E2

(c) Georg Thieme Verlag KG

Stuttgart · New York

ISSN 0013-726X

\section{ENDOSCOPY E-VIDEOS}

https://eref.thieme.de/e-videos

口居回 Endoscopy E-Videos is a free access online section, reporting 靣: on interesting cases and new techniques in gastroenterological endoscopy. All papers include a high quality video and all contributions are freely accessible online.

This section has its own submission website at

https://mc.manuscriptcentral.com/e-videos 